\title{
ANALISIS FAKTOR-FAKTOR YANG MEMPENGARUHI KAPABILITAS ANGGOTA DPRD TERHADAP PENGAWASAN KEUANGAN (APBD) DAERAH DI KABUPATEN MANOKWARI
}

\author{
Mega Wati Mandacan ${ }^{1}$, Harijanto Sabijono ${ }^{2}$, Treesje Runtu ${ }^{3}$ \\ ${ }^{1,2,3}$ Fakultas Ekonomi dan Bisnis, Jurusan Akuntansi, Universitas Sam Ratulangi, J1. Kampus Bahu, Manado, \\ 95115, Indonesia
}

E-mail : mandacanmega@gmail.com

\begin{abstract}
This study aims to determine the factors that affect the capability of members of parliament to the supervision of local finances (APBD). The variables used in this study are the dependent variable that is the supervision of regional finances (APBD) while the independent variables are personal background, political background, knowledge of DPRD members about the budget. The respondent is a member of the local parliament in the office of the local people's council of manokwari district. This study used multiple linear regression analysis with 30 respondents. The result shows that: (1) Personal Background has a positive influence on Regional Financial Supervision (APBD), (2) Political Background has negative effect on to Local Government Supervision (APBD), (3) Knowledge of DPRD Member on Budget has positive effect toward Local Government Supervision
\end{abstract}

Keywords : Personal Background, Political Background, Knowledge of DPRD Members About Budget, Regional Financial Supervision

\section{PENDAHULUAN}

Sejak dikeluarkannya peraturan tentang otonomi daerah yaitu Undang-Undang Nomor 32 Tahun 2004 tentang Pemerintah Daerah dan Undang-Undang Nomor 33 Tahun 2004 tentang Perimbangan Keuangan antara Pemerintah Pusat dan Daerah, maka kekuasaan atau tanggung jawab yang dibebankan kepada pemerintah daerah untuk mengelola daerahnya secara maksimal menjadi lebih besar. Hal ini ditujukan supaya distribusi dan pemanfaatan sumber daya alam nasional dapat merata dan terciptanya keseimbangan keuangan antara pemerintah daerah dan pemerintah pusat. Manajemen keuangan daerah dikelola secara penuh oleh pemerintah daerah. Supaya menajemen keuangan daerah dapat dipertanggungjawabkan secara sosial maka diperlukan komponen pokok yang harus dilaksanakan dan dipatuhi oleh pemerintah daerah yaitu pengelolaan keuangan daerah (APBD) secara transparan, akuntabel, efektif, dan efisien.

Pengetahuan anggota DPRD tentang anggaran dapat diartikan sebagai pengetahuan dewan terhadap mekanisme penyusunan anggaran mulai dari tahap perencanaan sampai pada tahap pertanggungjawaban serta pengetahuan dewan tentang peraturan perundangan yang mengatur pengelolaan keuangan daerah (APBD). Pengetahuan anggota DPRD tentang anggaran ini akan semakin penting apabila dikaitkan dengan mekanisme penyusunan dan penetapan APBD yang berlangsung saat ini diharapkan semakin tinggi kapabilitasnya dalam melakukan pengawasan keuangan daerah (APBD).

Pengawasan keuangan daerah merupakan satu rangkaian kegiatan pemantauan, pemeriksaan dan evaluasi terhadap pelakasanaan kebijakan politik. Pengawasan dilakukan untuk menjamin semua kebijakan program dan kegiatan yang dilakukan sesuai dengan aturan yang berlaku. Pengawasan keuangan daerah, dalam hal ini adalah pengawasan terhadap anggaran keuangan daerah/APBD. Menurut Undang-Undang Nomor 32 Tahun 2004 tentang Pemerintah Daerah pasal 42 menjelaskan bahwa : "DPRD mempunyai tugas dan wewenang 
melaksanakan pengawasan terhadap pelaksanaan Perda dan peraturan perundang-undangan lainnya, peraturan kepala daerah, APBD, kebijakan pemerintah dalam melaksanakan progaram pembangunan daerah dan kerjasama internasional di daerah". Berdasarkan dari undang-undang tersebut dapat diambil kesimpulan bahwa pengawasan keuangan daerah dilakukan oleh DPRD yang berfokus pada pengawasan terhadap pelaksanaan APBD.

\section{TINJAUAN PUSTAKA}

\subsection{Konsep Akuntansi}

Akuntansi adalah suatu aktivitas jasa yang terdiri dari mencatat, mengklarifikasikan, dan melaporkan kejadian atau transaksi ekonomi yang akhirnya akan menghasilkan suatu informasi keuangan yang akan dibutuhkan oleh pihak-pihak tertentu untuk pengambilan keputusan (Sujarweni, 2015:1).

\subsection{Konsep Akuntansi Pemerintahan}

\subsubsection{Pengertian Akuntansi Sektor Publik}

Siregar (2015 : 3) Akuntansi sektor publik merupakan aktivitas akuntansi yang dilakukan terhadap kerjadian dan transaksi keuangan organisasi sektor publik. Karena organisasi sektor publik yang paling utama adalah pemerintah, maka akuntansi sektor publik juga dapat dinyatakan sebagai aktivitas akuntansi yang diterapkan pada pemerintahan, baik Pemerintah Pusat maupun Pemerintah Daerah.

Akuntansi pemerintahan merupakan salah satu bangian dari akuntansi sektor publik selain dari akuntansi rumah sakit, akuntansi pendidikan, akuntansi yayasan dan akuntansi organisasi nirlaba lain yang didirikan bukan untuk mencari keuntungan semata-mata (Sujarweni,2015:18).

\subsection{Pengertian Keuangan Daerah}

Dalam Pasal 1 Peraturan Pemerintahan RI No. 58 Tahun 2005, Tentang Pengelolaan Keuangan Daerah menjelaskan bahwa keuangan daerah adalah semua hak dan kewajiban daerah dalam rangka penyelenggaraan daerah yang dapat dinilai dengan uang termasuk di dalamnya segala bentuk kekayaan yang berhubungan dengan hak dan kewajiban daerah tersebut dan tentunya dalam batas-batas kewenangan daerah. Keuangan daerah dituangkan sepenuhnya dalam APBD. APBD menurut Peraturan Pemerintah RI No. 58 Tahun 2005 tentang Pengelolaan Keuangan Daerah yaitu anggaran Pendapatan dan Belanja Daerah yang selanjutnya disingkat APBD adalah rencana keuangan tahunan pemerintahan daerah yang dibahas dan disetujui bersama oleh pemerintah daerah dan DPRD, dan ditetapkan dengan peraturan daerah.

\subsubsection{Fungsi DPRD Sebagai Pengawas Keuangan Daerah/APBD}

Pengawasan anggaran secara yuridis telah diatur baik di tingkat Undang-Undang, peraturan pemerintah dan juga dalam peraturan daerah mengenai pengelolaan keuangan daerah. Dalam konteks pengelolaan keuangan, pengawasan terhadap anggaran dijelaskan dalam Peraturan Pemerintah Nomor 58 Tahun 2005 tentang Pengelolaan Keuangan Daerah Pasal 132 yang menyatakan bahwa DPRD melakukan pengawasan terhadap pelaksanaan peraturan daerah tentang APBD. Pengawasan tersebut bukan berarti pemeriksaan, tapi lebih mengarah pada pengawasan untuk menjamin pencapaian sasaran yang telah ditetapkan dalam APBD. Hal ini sesuai juga dengan Keputusan Menteri Dalam Negeri No. 13 Tahun 2006 yang menyatakan bahwa untuk menjamin pencapaian sasaran yang telah ditetapkan, DPRD melakukan pengawasan atas pelaksanaan APBD, ini berarti bahwa pengawasan yang dilakukan oleh DPRD merupakan pengawasan eksternal dan ditekankan pada pencapainan sasaran APBD.

\subsubsection{Kapabilitas Anggota DPRD dalam Pengawasan Keuangan Daerah (APBD)}

Kapabilitas adalah kapasitas individu untuk menggunakan sumberdaya yang dimilikinya yang diintegrasikan dengan tujuan untuk mencapai tujuan akhir yang diinginkan. 
Kapabilitas memampukan individu untuk menciptakan dan mengeksploitasi peluang-peluang eksternal dan mengebangkan keunggulan yang ada ketika digunakan dengan pengetahuan dan keahlian yang dimilikinya. Pengetahuan merupakan salah satu faktor penting karena akan meningkatkan kapabilitas anggota DPRD. Apabila tingkat pendidikan dan pengetahuan anggota DPRD rendah, maka kapabilitasnya juga rendah. Hal ini akan berpengaruh terhadap rendahnya kemampuan untuk menjalankan fungsi dan peranannya dalam pengawasan keuangan daerah (APBD).

\subsection{Anggaran Pendapatan dan Belanja Daerah (APBD)}

Rahardjo (2013:28) menjelaskan APBD adalah suatu rencana operasional keuangan daerah, disatu pihak menggambarkan penerimaan pendapatan dan dilain pihak merupakan pengeluaran untuk membiayai pengeluaran rutin dan pengeluaran pembangunan dalamsatu tahun anggara. APBD juga merupakan instrument yang akan menjamin terciptanya disiplin dalam proses pengambilan keputusan terkait dengan kebijakan pendapatan maupun belanja daerah. Dalam Peraturan Pemerintah Nomor 58 tahun 2005 tentang Pengelolaan Keuangan Daerah mendefinisikan APBD adalah rencana keuangan tahunan pemerintah daerah yang dibahas dan disetujui bersama oleh pemerintah daerah dan DPRD, dan ditetapkan dengan peraturan daerah.

\subsection{Faktor-Faktor yang Mempengaruhi Kapilitas Anggota DPRD terhadap Pengawasan Keuangan Daerah \\ 2.5.1 Personal Background}

Menurut Sastroatmodjo (2006) dalam (Nurharyati, 2013) terdapat dua tingkat orientasi politik yang mempengaruhi perilaku politik, yaitu sistem dan individu. Lemahnya peran DPRD dalam kesalahan pada keuangan daerah (APBD) mungkin dikarenakan oleh lemahnya sistem politik atau individu sebagai aktor politik.

\subsubsection{Political Background}

Faktor lain yang mempengaruhi perilaku lembaga politik dalam hal ini DPRD adalah budaya politik (Almond dan Verba, 2009 dalam Witono dan Murni, 2013). Sebagai sebuah perwujudan dari sikap politik, perilaku politik tidak dapat dipisahkan dari political background. Political background ini meliputi beberapa dimensi, yaitu: pengalaman politik, pengalaman di DPRD, latar belakang partai politik, latar belakang ideologi partai politik dan asal komisi.

\subsubsection{Pengetahuan Anggota DPRD tentang Anggaran}

Pengetahuan merupakan persepsi responden tentang anggaran (RAPBD/APBD) dan deteksi terhadap pemborosan atau kegagalan, dan kebocoran anggaran. Sedangkan Nur dan Bambang (2012:78) di kutip oleh (Sjamsudin dan Syamsiar, 2012) menyebutkan bahwa pengetahuan pada dasarnya merupakan hasil dari proses melihat, mendengar, merasa dan berpikir yang menjadi dasar manusia dalam bersikap dan bertindak. Dengan demikian pengetahuan tentang sesuatu merupakan dasar bagi siapa saja dalam melakukan suatu tindakan atau bersikap terhadap sesuatu tersebut.

\subsection{Kapabilitas Anggota DPRD Terhadap Pengawasan Keuangan Daerah (APBD)}

Pengawasan merupakan satu rangkaian kegiatan pemantauan, pemeriksaan dan evaluasi terhadap pelakasanaan kebijakan politik. Pengawasan dilakukan untuk menjamin semua kebijakan program dan kegiatan yang dilakukan sesuai dengan aturan yang berlaku.

Pengawasan keuangan daerah, dalam hal ini adalah pengawasan terhadap anggaran keuangan daerah/APBD. Menurut Undang-Undang Nomor 32 Tahun 2004 tentang Pemerintah Daerah pasal 42 menjelaskan bahwa : "DPRD mempunyai tugas dan wewenang melaksanakan pengawasan terhadap pelaksanaan Perda dan peraturan perundang-undangan lainnya, peraturan kepala daerah, APBD, kebijakan pemerintah dalam melaksanakan progaram pembangunan daerah dan kerjasama internasional di daerah". Berdasarkan dari 
undang-undang tersebut dapat diambil kesimpulan bahwa pengawasan keuangan daerah dilakukan oleh DPRD yang berfokus pada pengawasan terhadap pelaksanaan APBD.

Pengawasan menurut Keputusan Presiden Nomor 74 Tahun 2001 tentang Tata Cara Pengawasan Penyelenggaraan Pemerintah Daerah. Pasal 1 ayat (6) menyebutkan, bahwa : "Pengawasan pemerintah daerah adalah proses kegiatan yang ditujukkan untuk menjamin agar pemerintah daerah berjalan sesuai dengan rencana dan ketentuan peraturan perundangundangan yang berlaku".

\subsection{Penelitian Terdahulu}

Isnurhadi, Zulkarnain Ishak, dkk. 2012. Judul skripsi The effects of budget quality on budget control: Knowledge of budget as moderating variable. Tujuan untuk menguji pengaruh pengetahuan anggaran sebagai variabel moderat terhadap kualitas anggaran dan efektivitas pengendalian anggaran. Metode yang digunakan kuantitaif. Hasil penelitian menunjukkan pengaruh pengetahuan anggaran terhadap kualitas anggaran dan efektivitas pengendalian anggaran yang ditemukan lemah atau tidak siginifikan.

\section{METODE PENELITIAN}

\subsection{Jenis Penelitian}

Jenis penelitan ini adalah data kualitatif yang di kuantitatifkan dengan menggunakan skala Likert Lima (5) poin. Skala ini menggunakan skala ordinal yang menggunakan angka yang mengandung suatu tindakan. Ukuran ini tidak memberikan nilai absolut terhadap objek tapi hanya memberikan urutan dimana setiap jawaban yang ada dalam kuisioner diberikan angka skor lima (5) untuk yang tertinggi dan skor satu (1) untuk yang terendah, (Moh. Nasir, 2013 : 339). Dengan keterangan : sangat setuju=SS diberi skor lima (5), setuju=S diberi skor empat (4), kurang setuju=KS diberi skor tiga (3), tidak setuju=TS diberi skor dua (2), dan

\subsection{Tempat Dan Waktu Penelitian}

Tempat penelitian dilakukan pada Kantor DPRD Manokwari dengan alamat Jl. Esau Sesa, Sowi Gunung, Kabupaten Manokwari, Papua Barat. Waktu pelaksanaan penelitian dilakukan pada bulan Oktober-Desember 2017

\subsection{Teknik Pengumpulan Data}

Adapun prosedur penelitian yang digunakan dalam skripsi ini adalah :

1. Survei Pendahuluan

2. Survey lapangan

\subsection{Defiinisi Operasional dan Pengukuran Variabel}

1. Personal Background $\left(\mathrm{X}_{1}\right)$ :

2. Political Background $\left(\mathrm{X}_{2}\right)$ :

3. Pengetahuan Dewan Tentang anggaran $\left(\mathrm{X}_{3}\right)$ :

4. Pengawasan Keuangan Daerah (APBD) (Y):

\subsection{Populasi dan Sampel}

Populasi adalah wilayah generalisasi yang terdiri atas objek atau subjek yang mempunyai kuuantitas dan karakteristik tertentu yang ditetapkan oleh peneliti untuk dipelajari dan kemudian ditarik kesimpulan , (Sugiyono, 2014 : 89) dan Kuncoro, 2012 : 103). Populasi dalam penelitian ini adalah seluruh anggota DPRD pada Dewan Perwakilan Rakyat Daerah Kannbupaten Manokwari periode tahun 2014-2019 yang berjumlah 30 orang.

\subsection{Metode dan Teknik Analisis}

\subsubsection{Pengujian Kualitas Data}

Sebelum melakukan analisi data, penulis terlebih dahulu melakukan pengujian kualitas data yang diperoleh. Uji kualitas data yang dilakukan untuk meyakinkan kualitas data yang akan diolah, telah valid.

1. Uji Validitas

2. Uji Reabilitas 


\subsubsection{Asumsi Model Klasik}

Karena penelitian ini menggunakan tiga variable independen dan satu variabel dependen, maka metode statistik yang dingunakan adalah analisis regresi linear berganda. Sebelum melakukan analisis regresi linear berganda, terlebih dahulu dilakukan asumsi klasik. Dalam literatur ekonometrika dikemukakan beberapa asumsi klasik yang harus dipenuhi oleh suatu model tersebut bisa dipakai.

\subsubsection{Regresi Linear Berganda}

Secara umum, analisis regresi pada dasarnya adalah studi mengenai ketergantungan variable dependen (terikat) dengan satu atau lebih variable independen (bebas), dengan tujuan untuk mengestimasi dan/atau memprediksi rata-rata populasi atau nilai variabel independen yang diketahui (Gujarati di kutip oleh Ghozali, 2012 : 125).

\subsubsection{Koefisien Determinasi $\left(\mathbf{R}^{2}\right)$}

Koefisien determinasi $\left(\mathrm{R}^{2}\right)$ pada intinya mengukur seberapa jauh kemampuan model dalam menerangkan variasi variabel dependen. Nilai koefisien determinasi adalah antara nol (0) dan satu (1). $\mathrm{R}^{2}$ yang kecil berarti kemampuan variabel-variabel independen dan menjelaskan variabel dependen sangat terbatas. Nilai yang mendekati satu berarti variabelvariabel independen memberikan hampir semua informasi yang dibutuhkan untuk memprediksi variasi variabel dependen.

\subsubsection{Uji Hipotesis}

Dalam bagian ini akan dijelaskan mengenai langkah-langkah pengujian hipotesis. Adapun langkah langkah pengujian hipotesis yang dingunakan dalam penelitian ini adalah sebagai berikut (Kuncoro, 2013 : 218-220): Uji F dan Uji T

\section{HASIL PENELITIAN DAN PEMBAHASAN \\ 4.1 Hasil Penelitian}

Dari Tebel 4.3 dapat dilihat bahwa mayoritas responden adalah pria terdiri dari 22 orang dengan nilai presentase sebesar $73 \%$. Sedangakan responden wanita hanya terdiri dari 8 orang dengan nilai presentase sebesar $27 \%$. Usia responden sangat bervariasi. Usia 30-39 tahun sebanyak 5 orang dengan nilai presentase 17\%, usia 40-49 tahun sebanyak 15 orang dengan nilai presentase sebesar 50\%, usia 50-59 tahun sebanyak 7 orang dengan nilai presentase sebesar 23\%, dan usia 60-69 tahun sebanyak 3 orang dengan nilai presentase sebesar $10 \%$, dengan tingkat Pendidikan terakhir responden sebagian besar adalah Strata/ Sarjana yaitu sebanyak 22 orang dengan nilai presentase $73 \%$, kemudian Diploma (I, II,III) sebanyak 5 orang dengan nilai presentase $17 \%$ dan SMA sebanyak 3 orang dengan presentase sebesar $10 \%$. Bidang-bidang Pendidikan responden yaitu untuk Teknik sebanyak 2 orang dengan nilai presentase $7 \%$, Perikanan sebanyak 1 orang dengan nilai presentase $3 \%$, Ilmu Sosial dan Politik sebanyak 7 orang dengan nilai presentase 23\%, Ekonomi sebanyak 9 orang dengan nilai presentase $30 \%$, Hukum sebanyak 8 orang dengan nilai presentase $27 \%$ dan bidang pendidikan yang tidak diketahui atau lainnya sebanyak 3 orang dengan nilai presentase $10 \%$.

Adapun pekerjaan responden sebelum menjadi anggota DPRD sangat beragam dan paling banyak adalah Wiraswasta sebanyak 19 orang dengan nilai presentase $63 \%$, Pengawai Swasta sebanyak 4 orang dengan nilai presentase 13\%, Pengawai Negeri Sipil sebanyak 3 orang dengan nilai presentse 10\%, sedangkan Pengacara dan Dosen masing-masing sebanyak 2 orang dengan nilai presentase $7 \%$ untuk masing-masing pekerjaan. Dalam penelitian ini responden memiliki alasan komisi, untuk komisi A dan komisi B sebanyak 7 orang dengan presentase $23 \%$ untuk masing-masing komisi, komisi $\mathrm{C}$ sebanyak 11 orang dengan nilai presentase $32 \%$ dan yang memiliki jabatan unsur pimpinan sebanyak 5 orang dengan nilai presentase $17 \%$. Kemudian pengalaman responden manjabat sebagai anggota DPRD selama 1 periode sebanyak 20 orang dengan nilai presentase 67\%, 2 periode sebanyak 6 orang 
dengan nilai presentase $20 \%$, dan 3 periode sebanyak 4 orang dengan nilai pesentase $13 \%$. Selanjutunya, ideologi partai responden untuk Nasionalis sebanyak 21 orang dengan nilai presentase 70\%, Nasionalis Agama sebanyak 3 orang dengan nilai presentase 10\%, Agama sebanyak 5 orang dengan nilai presentase $17 \%$, dan Demokrat sebanyak 1 orang dengan nilai presentase $3 \%$. Sedangkan pengalam berpolitik responden untuk 1-10 tahun sebanyak 15 dengan nilai presentase 50\%, 11-20 tahun sebanyak 14 orang dengan nilai presentase $47 \%$, dan 21-30 tahun sebanyak 1 orang dengan nilai presentase $3 \%$.

Untuk setiap variable Personal Background $\left(\mathrm{X}_{1}\right)$, Political Background $\left(\mathrm{X}_{2}\right)$, Pengetahuan Anggota Dewan tentang Anggaran $\left(\mathrm{X}_{3}\right)$ dan Kapabilitas Anggota DPRD Tehadap Pengawasan Keuangan Daerah (APBD) (Y) masing-masing terdapat 6 pertanyaan sehingga total keseluruhan pertanyaan berjumlah 24 pertanyaan.

Hasil jawaban responden yang diperoleh selanjutnya ditabulasi dengan menggunakan bantuan Microsoft Excel dengan tingkat skor sesuai dengan skala Likert. Adapun hasil tabulasi data dapat dilihat pada lampiran.

\subsubsection{Uji Kualitas Data}

Data utama yang dingunakan dalam penelitian ini adalah data primer, dengan kuesioner tertutup sebagai alat utama untuk memperoleh data. Untuk menyakinkan kualitas data yang akan diolah, terlebih dahulu diuji validitas dan realibilitasnya sebagai berikut.

\section{Uji Validitas}

Uji validitas dimaksudkan untuk mengukur sah atau valid tidaknya suatu kuesioner. Suatu kuesioner dikatakan valid apabila pertanyaan pada kuesioner maupun mengungkapkan sesuatu yang tidak diketahui. Uji validitas yang dingunakan adalah dengan menggunakan korelasi Bilvariate antara masing-masing skor indikator dengan total skor konstruk. Suatu indikator pernyataan dikatakan valid apabila korelasi antara masing-masing indikator menunjukkan hasil yang signifikan.

\section{Uji Reabilitas}

Uji reliabilitas adalah indikator untuk mengukur kuesioner yang merupakan indikator dari suatu variabel. Alat ukur dinyatakan reliabel jika nilai koefisien alpha di atas 0,60. Berikut ini uji reliabilitas dari Personal Background, Political Background, Pengetahuan Anggota DPRD Tentang Anggaran, Pengawasan Keuangan Daerah (APBD).

\subsubsection{Uji Asumsi Klasik}

Pengujian asumsi klasik dilakukan untuk mengetahui hubungan antara variabel bebas. Berdasarkan hasil pengelolaan data yang menggunakan program aplikasi SPSS versi 21, maka diperoleh interprestasi dari hasil pengujian asumsi klasik sebagai berikut.

\section{Uji Normalitas}

Uji normalitas digunakan untuk mengetahui sebuah regresi telah berdistribusi normal atau tidak. Dalam penelitian ini uji normalitas dilakukan dengan uji statistik yaitu one sample kolmogorov smirnov test.

\section{Uji Asumsi Klasik Heterokedatisitas}

Untuk mendeteksi adanya heterokedatisitas, dapat dilakukan dengan melihat ada atau tidaknya pola tertentu pada grafik Scatter Plot. Jika grafik Scatter Plot tidak membentuk pola yang teratur atau menggambarkan pola tertentu seperti bergelombang, melebar ataupun menyempit, tetapi menyebar diatas maupun dibawah nilai nol dibawah sumbu Y, berarti dapat dikatan modelregresi terbebas dari heterokedatisitas.

\section{Uji Asumsi Klasik Multikolinearitas}

Uji multikolinearitas adalah suatu keadaan dimana antar variabel bebas saling mempengaruhi dengan kuat. Suatu model regresi dinyatakan bebas dari multikolinearitas jika mempunyai niali VIF $<10.00$ dan mempunyai tolerance diatas 0,10 dengan model regresi. 


\subsubsection{Koefisien Determinasi $\left(\mathbf{R}^{2}\right)$}

Koefisien determinasi diperlukan untuk mengukur seberapa besar pengaruh personal background $\left(\mathrm{X}_{1}\right)$, political background $\left(\mathrm{X}_{2}\right)$, dan pengetahuan anggota DPRD tentang anggaran $\left(\mathrm{X}_{3}\right)$ terhadap pengawasan keuangan daerah (APBD) $(\mathrm{Y})$.

Koefisien determinnasi ini dingunakan karena dapat menjelaskan kebaikan dari model regresi dalam memprediksi variable dependen. Semakin tinggi nilaikoefisien determinasi maka akan semakin baik pula kemampuan variabel independen dalam menjelaskan variabel dependen (Ghozali, 2012). Nilai koefisien adalah antara nol dan satu.

Nilai $\mathrm{R}^{2}$ yang kecil berarti kemampuan variabel-variabel independen dalam menjelaskan variasi variabel-variabel dependen amat terbatas. Nilai yang mendekati 1 berari variabelvariabel independen memberikan hamper semua informasi-informasi yang dibutuhkan untuk memprediksi variasi variabel dependen.

\subsubsection{Analisis Regresi Linear Berganda}

Regresi linear berganda dingunakan untuk mengetahui apakah Personal Background, Political Background, Pengetahuan Anggota DPRD Tentang Anggaran berpengaruh secara serentak terhadap Pengawasan Keuangan Daerah (APBD). Model analisis regresi linear berganda yang dingunakan untuk menguji hipotesi adalah sebagai berikut.

Dimana:

$$
\mathbf{Y}=\boldsymbol{\alpha}+\boldsymbol{\beta}_{1} \mathbf{X}_{1}+\boldsymbol{\beta}_{2} \mathbf{X}_{2}+\boldsymbol{\beta}_{3} \mathbf{X}_{3}+\varepsilon
$$

$$
\begin{aligned}
& Y=\text { Pengawasan Keuangan Daerah (APBD) } \\
& \alpha=\text { Konstanta } \\
& \beta_{1}=\text { Koefisien regresi untuk } X_{1} \\
& \beta_{2}=\text { Koefisien regresi untuk } X_{2} \\
& \beta_{3}=\text { Koefisien regresi untuk } X_{3} \\
& X_{1}=\text { Pesonal Background } \\
& X_{2}=\text { Political Background } \\
& X_{3}=\text { Pengetahuan Anggota DPRD Tentang Anggaran } \\
& \varepsilon=\text { error }
\end{aligned}
$$

\subsubsection{Pengujian Hipotesis}

Hipotesis merupakan suatu asumsi atau anggapan yang bisa benar atau bisa salah mengenai sesuatu hal dan dibuat untuk menjelaskan sesuatu hal tersebut sehingga memerlukan pengecekan lebih lanjut (Ma'ruf Abdullah (2015; 297).

\subsection{Pembahasan}

\subsubsection{Pengaruh personal background $\left(\mathrm{X}_{1}\right)$ terhadap Pengawasan Keuangan Daerah (APBD) (Y)}

Hasil analisis data dan pengujian hipotesis menunjukkan bahwa Personal Background $\left(\mathrm{X}_{1}\right)$ berpengaruh positif terhadap pengawasan keuangan daerah (APBD) (Y) pada DPRD Kabupaten Manokwari, dimana $\mathrm{t}_{\text {hitung }}=2.527>\mathrm{t}_{\text {tabel }}=1.706$ pada tingkat signifikansi yang dipersyaratkan yaitu 0.05 sehingga dapat disimpulkan personal background yang baik dapat meningkatkan kapabilitas anggota DPRD terhadap pengawasan keuangan daerah (APBD) pada DPRD di Kabupaten Manokwari.

Hal ini konsisten dengan penelitian terdahulu oleh (Widyaningsih, 2012) yang menyatakan bahwa sumber daya manusia merupakan pilar penyangga utama sekaligus penggerak roda organisasi dalam usaha mewujudkan elemen organisasi yang sangat penting, karena harusnya dipastikan sumber daya ini harus dikelola sebaik mungkin dan akan mampu memberikan konstribusi secara optimal dalam upaya pencapaian tujuan organisasi. 


\subsubsection{Pengaruh Political Background $\left(\mathrm{X}_{2}\right)$ terhadap Pengawasan Keuangan Daerah (APBD) (Y)}

Hasil analisis data dan pengujian hipotesis menunjukkan bahwa Political Background $\left(\mathrm{X}_{2}\right)$ secara berpengaruh negatif terhadap pengawasan keuangan daerah (APBD) (Y) pada DPRD Kabupaten Manokwari atau tidak berpengaruh signifikan, namun secara Bersamabersama (simultan) berpengaruh signifikan terhadap pengawasan keuangan daerah (APBD) pada DPRD di Kabupaten Manokwari.

Dari pengujian hipotesis menunjukkan bahwa political background anggota DPRD belum berada pada kualifikasi ideal dalam arti memahami benar hak, tugas dan wewenangnya dalam menjalankan tugasnya sebagai anggota DPRD. Sehingga political background berpenngaruh negative terhadap pengawasan keuangan daerah (APBD). Hal ini didukung dengan teori yang dikemukakan oleh La Palombra (2007) di kutip oleh (Sjamsudin dan Syamsiar, 2012), ada beberapa faktor yang mempengaruhi sikap, perilaku, dan kapabilitas anggota lengislatif yaitu institusi politik, partai politik, karakteristik pribadi, pengalaman politik dan sifat pemilih.

\subsubsection{Pengaruh Pengetahuan Angggota DPRD Tentang Anggaran $\left(X_{3}\right)$ terhadap Pengawasan Keuangan Daerah (APBD) (Y)}

Hasil analisis data dan pengujian hipotesis menunjukkan bahwa Pengetahuan Anggota DPRD Tentang Anggaran $\left(\mathrm{X}_{3}\right)$ berpengaruh positif terhadap pengawasan keuangan daerah (APBD) (Y) pada DPRD Kabupaten Manokwari, dimana $t_{\text {hitung }}=2.508>t_{\text {tabel }}=1.706$ pada tingkat signifikansi yang dipersyaratkan yaitu 0.05 sehingga dapat disimpulkan Pengetahuan Anggota DPRD Tentang Anggaran dapat meningkatkan kapabilitas anggota DPRD terhadap pengawasan keuangan daerah (APBD) di Kabupaten Mannokwari.

Dalam menjalankan tugas dan peran annggota DPR, kapasitas, dan profesi dewan sangat ditentukan oleh kemampuan dalam memproduk suatu kebijakan. Kapabilitas dan kemampuan dewan yang harus dimiliki antara lain pengetahuan, keterampilan, dan Pengalaman dalam menyusun berbagai peraturan daerah.

Hal ini didukung dengan teori yang dikemukakan oleh La Palombra (2007) di kutip oleh (Sjamsudin dan Syamsiar, 2012), ada beberapa faktor yang mempengaruhi sikap, perilaku, dan kapabilitas anggota lengislatif yaitu institusi politik, partai politik, karakteristik pribadi, pengalaman politik dan sifat pemilih. Dengan mengetahui tentang anggaran diharapkan anggota DPRD dapat mendeteksi adanya pemborosan dan kebocoran anggaran.

\section{KESIMPULAN DAN SARAN}

\subsection{Kesimpulan}

1. Berdasarkan pembahasan hasil analisis dalam penelitian ini maka persamaan regresi linear berganda adalah sebagai berikut:

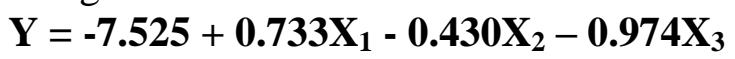

Untuk koefisien variabel $\mathrm{X}_{1}$ (Personal Background) adalah sebesar positif (0.733). Ini berarti variabel latar belakang pribadi terdapat pengawasan keuangan daerah (APBD) memiliki pengaruh positif atau searah terhadap variabel Y (Pengawasan Keuangan Daerah. Selanjutnya untuk koefisien variabel $\mathrm{X}_{2}$ (Political Background) adalah sebesar negatif(-0.430) Ini berarti variabel Political Background memiliki pengaruh negatif atau tidak searah terhadap variabel Y (Pengawasan Keuangan Daerah (APBD). Dan untuk koefisien variabel $\mathrm{X}_{3}$ (0.974) Pengetahuan Anggota DPRD tentang Anggaran) adalah sebesar positif (0.974). Ini berarti variabel Pengetahuan Anggota DPRD tentang Anggaran memiliki pengaruh positif atau searah terhadap variabel Y (Pengawasan Keuangan Daerah (APBD).

2. $\quad$ Dari hasil perhitungan $R$ Square maka dapat diketahui nilai $R$ Square yang diperoleh adalah sebesar 0.818 atau $81,8 \%$. Angka ini menunjukkan bahwa pengawasan 
keuangan daerah (APBD) pada DPRD Kabupaten Manokwari dipengaruhi oleh faktor oleh personal background, political background, pengetahuan anggota DPRD tentang anggaran sebesar $81,8 \%$, sedangkan sisanya sebesar $18,2 \%$ dijelaskan oleh faktorfaktor atau variabel lain yang tidak diteliti dalam penelitian ini.

3. Dari hasil uji $\mathrm{F}$ dapat diketahui $\mathrm{F}_{\text {hitung }}=45.480$ dan $\mathrm{F}_{\text {tabel }}=2.960$, Nampak bahwa $\mathrm{F}_{\text {hitung }}$ $>\mathrm{F}_{\text {tabel }} \mathrm{H}_{0}$ ditolak dan $\mathrm{Ha}$ diterima artinya personal background $\left(\mathrm{X}_{1}\right)$, political background $\left(\mathrm{X}_{2}\right)$ dan pengetahuan anggota DPRD tentang anggaran $\left(\mathrm{X}_{3}\right)$ berpengaruh signifikan terhadap pengawasan keuangan daerah (APBD)

4. Dari hasil uji $\mathrm{t}$ untuk variabel $\mathrm{X}_{1}$ (personal background) $=2.525$ dan $\mathrm{t}_{\text {tabel }}=1.706$. karena $t_{\text {hitung }}>t_{\text {tabel }}$ maka $\mathrm{H}_{0}$ ditolak dan Ha diterima. Artinya variabel personal background berpengaruh signifikan terhadap pengawasan keuangan daerah (APBD). Dan hasil uji $\mathrm{t}$ untuk varibel $\mathrm{X}_{2}$ (political background) $=-1.404$ dan $\mathrm{t}_{\text {tabel }}=1.706$. karena $\mathrm{t}_{\text {hitung }}<\mathrm{t}_{\text {tabel }}$ maka $\mathrm{H}_{0}$ diterima da Ha ditolak. Artinya variabel political background tidak berpengaruh signifikan terhadap pengawasan keuangan daerah (APBD). Dan hasil uji t variabel $\mathrm{X}_{3}$ (pengetahuan anggota DPRD tentang anggaran $)=2.508$ dan $t_{\text {tabel }}=1.706$. karena $t_{\text {hitung }}>t_{\text {tabel }}$ maka $\mathrm{H}_{0}$ ditolak dan Ha diterima. Artinya variabel pengetahuan anggota DPRD tentang anggaran sangat berpengaruh terhadap pengawasan keuangan daerah (APBD).

\subsection{Saran}

1. Bagi pemerintahan setempat, terlebih bagi anggota DPRD untuk lebih meningkatkn kapabilitas (kemampuan) terhadap pengawasan keuangan daerah (APBD) diharpkan memiliki Personal Background, Political Background, dan Pengetahuan Anggota DPRD tentang Anggaran yang baik.

2. Penelitian selanjutnya menggali factor-faktor-faktor lain atau variabel-variabel lain yang berpengaruh terhadap peran DPRD terhadap pengawasan keuangan daerah (APBD) dengan mempertimbangkan keterbatasan yang ada didalam penelitian ini.

3. Agar memberikan tambahan informasi dan menimbulkan inisiatif untuk melakukan penelitian pada masa yang akan datang dan menjadi salah satu sumber ilmu, khususnya kuntansi Sektor Publik dan difokuskan pada bidang anggaran, maka pada saat pengambilan data sebaiknya disaat pemerintah daerah sedang menyusun anggaran, sehingga informan yang diperoleh bukan hanya pada aparat pemerintah saja, tetapi dapat diperoleh dari masyarkat disaat penjaringan aspirasi.

\section{DAFTAR PUSTAKA}

Arif Kurniawan,2012. Pengaruh Partisipasi Masyarakat, Transparansi Kebijakan Publik, Akuntabilitas Publik Dan Pengetahuan Dewan Tentang Anggaran Terhadap Penyusunan APBD.

Baswir, Revrisond. 2011. Akuntansi Pemerintah Indonesia. Edisi ketiga. BPFE: Yogyakarta

Belkaoui,Ahmed Riahi. 2011. Teori Akuntansi, Ahmed Riahi. 2011. Teori Akuntansi Buku 2. Salemba Empat, Jakarta

Ghozali, Imam. 2011. Aplikasi Analisis Multivariate Dengan Program SPSS. Badan Penerbit Universitas Diponogoro: Semarang.

Halim, A. dan Iqbal M., 2012. Pengelolaan Keuangan Daerah.UPP STIM YKPN: Yogyakarta

Hery,2013. Teori Akuntansi. Lembaga penerbit FE-UI. Jakarta

Jimung, Martinus, Maschab, Manshuri, dan Karim, Abdul Gaffar. 2004. Kemampuan Anggota Dewan dalam Melaksanakan Fungsi Legislasi dan Pengawasan, Jurnal Sosiosains, 17(3). Juli 2004. pp. 561-581. 
Kuncoro. Mudrajad. 2009. Metode Riset untuk Bisnis \& Ekonomi Edisi 3. Erlangga: Jakarta Mardiasmo . 2014. Akuntansi Sektor Publik . Andi , Yogyakarta

Mayasari, R. 2012. Pengaruh Kualitas Anggota Dewan Terhadap Pengawasan APBD Dengan Tata Pemerintahan Yang Baik Sebagai Variabel Moderating. Jurnal Ekonomi dan Informasi Akuntansi 2(1): 48-64.

Nurhayati. 2013. Pengawasan DPRD Terhadap Pelaksanaan Peraturan Daerah (Perda) Tentang APBD Kota Padang Panjang Tahun 2006. Artikel. Program Pasca Sarjana Universitas Andalas. Padang

Purwanto, E. A. dan Dyah Ratih Sulistyaastuti. 2013. Metode Penelitian Kuantitatif Untuk Administrasi Public Dan Masalah-Masalah Sosial. Yogyakarta: Gava media

Republik Indonesia, 2001. Keputusan Presiden Nomor 74 Tahun 2001 tentang Tata Cara Pengawasan Penyelenggaraan Pemerintahan Daerah.

Republik Indonesia, 2004. Undang-Undang Repuublik IndonesiaNomor 14 Tahun 2004 tentang Perimbangan Keuangan Antara Pemerintah Pusat dan Pemerintah Daerah.

Republik Indonesia, 2004. Peraturan Pemerintah Republik Indonsia Nomor 32 Tahun 2004 tentang Pengelolaan Keuangan Daerah.

Republik Indonesia, 2004. Peraturan Pemerintah Republik Indonsia Nomor 33 Tahun 2004 tentang Perimbangan Keuangan Antar Pemerintah Pusat dan Daerah. 